\title{
CAUSE OF STRESS AMONG PRIVATE BANK EMPLOYEES: AN ANALYSIS
}

\author{
Manjunatha M K. ${ }^{* 1}$ (iD, Dr. T. P. Renukamurthy ${ }^{2}$ \\ ${ }^{* 1}$ Research Scholar, Visvesvaraya Technological University, Karnataka, India \\ 2 Professors, Visvesvaraya Technological University, Karnataka, India
}

DOI: https://doi.org/10.29121/granthaalayah.v8.i12.2020.2560

Article Type: Research Article

Article Citation: Manjunatha M K., and Dr. T. P. Renukamurthy. (2020). CAUSE OF STRESS AMONG PRIVATE BANK EMPLOYEES: AN ANALYSIS. International Journal of Research GRANTHAALAYAH, 8(12), 36-47. https://doi.org/10.29121/granthaa layah.v8.i12.2020.2560

Received Date: 26 November 2020

Accepted Date: 25 December 2020

Keywords:

Stress

Bank Employee

Private Banks

Demographic Variables

Designation

\section{ABSTRACT}

Purpose of this study is examining the cause of stress among selected private banking employees. Stratified sampling method was used to carry out the data collection. For this employee of various private banks were chosen. A questionnaire with 12 items with dichotomous (Yes-1, NO-2) were developed and tested for reliability and prior to the distribution of questionnaire. 253 respondents were selected from various private banks in Mysore district, Karnataka state India. The survey questionnaire was sent via email, requesting to complete it. The questionnaire includes 11 demographic information's and statements to measure. Chi-Square analysis was carried out to examine the cause of stress among employee using SPSS21. We found that designations have significant influence on employee and the other factors of do not have any significant influence on employee. Therefore, we concluded that in private banks demographic variable such as designation creates stress in all aspects. Future research should consider a larger sample from leading sectors where job natures are similar. Analysis should be more rigorous, where Amos could be used for analysis.

\section{INTRODUCTION}

In our fast-paced world Stress refers to the strain from the conflict between our external environment, leading to emotional and physical pressure. Stress is inevitable in life and with increasing complexities, aspirations and uncertainties associated with socio-economic and cultural upheavals; stress is only likely to increase. In work situations, organizational stress due to unclear job tasks, overburdened of work, fatigue, unrealistic deadlines, reward system, insecure working environment, unsupportive supervisors, non-cooperative colleagues, less participation, less control over job, frequent dealing of public, extensive working hours of other factors has motivated researchers to explore the cause and consequences of stress (Shanabhogara Raghavendra et al.2013),

Stress has become a very common phenomenon of routine life, and an unavoidable consequence of the ways in which society has changed. This change has occurred in terms of science and technology, industrial growth, urbanization, modernization, automation and expanding population, unemployment, and stress on the other. The term "stress" was first used by Selye (1936) in the literature on life sciences, describing stress as "the force, pressure or strain exerted upon a material object or person which state."

(C) 2020 The Author(s). This is an open access article distributed under the terms of the Creative Commons Attribution License, which permits unrestricted use, distribution, and reproduction in any medium, provided the original author and source are credited. 
Manjunatha M K., and Dr. T. P. Renukamurthy

\section{LITERATURE REVIEW}

Madhu et al. (1990) [1] The study explained that Role conflict and role ambiguity are significant factors of stress which are experienced by many banking employees and also, they were explained about role ambiguity will cause depression, low self-esteem, and lower level of job involvement.

Spreitzer et al. (1997) [2] Opined that the employees who are very closely connected with their job, experience more stress and felt that they have the necessary skills and influence.

Barkat and Asma (1999) [3] Found that female employees experience low levels of stress than their male counterparts.

Pattanayak and Sarangi (2000) [4]: This study was conducted in public sector employees; they had categorized employees into old and new public sector banks. Total organizational stress was experienced differently by executive and non-executive, new versus old public sectors subjects and production versus service subjects.

Jex and Bliese (2001) [5] The study was conducted in US Army and revealed that three-way interactions are important factors for active coping and avoidance of coping and were examined the effect of self-efficacy on stressorstrain relations.

Klink J et al. (2001) [6] This study explained about occupational stress reduction by various stress management interventions and investigated that behavioural approach will have more effective than the interventions.

Suneel Khanna (2001) [7] Discusses the double-edged sword of modern information technology, like email, cell phones and laptops that were meant to make life simpler. Conveniences of such technologies; Stress caused by the unrelenting flow of information; Disadvantage of telecommuting; Burnout caused by the struggle of employees to keep pace.

Bhattacharya, et.al., (2007) [8] Conducted a survey to study distress. Investigated the women employees will experience more distress.

Rao and Pradhan (2007) [9] The authors attempted to survey by identifying various dimensions for software professionals. The study came out with the results that there is a significant difference difference between among personality.

Raghavan, et.al (2008) [10] This study was conducted for IT professionals to study various types of stress factors and found that removing of role ambiguity facilitation of work can ease for work-related stress.

Randhir Singh Ranta, (2009) [11] this study investigates present-day life experiences fair share of stress. The stressed police officers transfer their stress to their colleagues and consequently on the public.

Sankpal S., Negi P., Vashishtha J. (2010) [12] this study aims at examining the role of stress among public and private sector bank employees. Various stress factors were identified to conduct the survey and they came out with the result that private banking employees are under higher stress than the public sector bank employees.

Pratibha G. (2010) [13] the research was carried out by focusing on distress level on the quality of work-life among private bank employees. Distress hurts the quality of life.

Singh and Ruchi (2010) [14] this study was conducted on private and public sector employees to identify the effect of role stress. It was found that private sector bank employees have high-stress management than public sector banks.

S. Katyal M. Jain and B. Dhanda (2011) [15] Opine that employees working in non-nationalized banks are at a higher level of stress than nationalized bank employees. It also reveals that there is a highly significant difference in job and stress levels of employees working in nationalized and non-nationalized banks.

K.S.Sathyanaraynan et al. (2011) [16] The authors studied the impact of stress on the IT industry and its remedial measures. The study observed that due to various job-related issues the employees often feel stress in their jobs and a result of this the productive outcome decreases. This is the biggest IT challenge that the industry is facing at present and to tackle these issues various stress management programmes have also been incorporated.

Laiba Dar et al (2011) [17] Expressed their views that in recent years stress has been on the rise across all spheres of life, specifically at the workplace. The chi-square test and t-test were used to test the hypothesis and showed that stress will have subjective effects.

Mohamed Irfann Ismail (2011) [18] This study was conducted to identify various dimensions of stress which influence employees working in the financial industry, showed in the financial industry intensification and role ambiguity are the main types of stress will influence the financial sector. 
Darling, John et al (2011) [19] this study covered the previous research on stress management. The study discovered that attention, vision, trust and confidence are the four strategies that provide insight into organizational development

Makhbul, Zafir Mohd et al. (2011) [20] this study focused on Ergonomics and Work Stress Issues in Banking Sector. The regression analysis was showed that health factors can have an impact on work stress.

\section{NEED FOR THE PRESENT STUDY}

Stress and its disastrous consequences have been observed in all the sectors, industries and organizations. One such industry which has gone into massive changes over the last twenty years is the banking industry. Banking industry is the most important constituent of the financial sector of any economy. With the opening of the banking sector Private sector banks had to face fierce competition from public and foreign banks. It is here, the banks understood that infrastructure, and capital and technology are replicable but not human capital which is a valuable resource for achieving competitive edge. Private sector banks too started introducing newer products and services to keep the profit margin at a safer level and survive in the market. Competent and energetic work force with high skill level both hard and soft became crucial to market the products and services and cater to the needs and requirements of the customers. With this background the present study made an attempt to understand the cause of stress among private banking employee.

\section{OBJECTIVES OF THE STUDY}

To study the causes of stress among employees in the selected banks.

\section{HYPOTHESES}

$H(0)$ : There is no significant association between the causes of stress among employees in the selected banks

$H$ (1): There is a significant association between the causes of stress among employees in the selected banks

Research Methodology Research Design Descriptive Research Design Is Adopted for This Study. Descriptive Research Includes Surveys and Fact-Finding Enquiries of Different Kinds.

Sample Size: The Study Sample Constitutes 253 Private Bank Employees in Mysuru District.

Sampling Area: The Study Is Conducted for Employees of Karnataka Bank, Kotak Mahindra Bank, Hdfc Bank, Icici Bank, Axis Bank of Mysuru District.

Sampling Design: Stratified Sampling Design Is Used in This Survey.

Collection of Data: Primary Data Is That Which Consist of Original Information for A Specific Purpose. Primary Data Is Collected Through Questionnaires. Secondary Data Consist of Information Which Has Already Been Collected by Someone Else for Some Other Purpose. Secondary Data Is Collected Through Journal, Websites and Books.

Research Instrument: Questionnaire Is the Data Collection Instrument Used in The Study. All the Questions in The Questionnaire Are Organized in Such A Way That All the Relevant Information Is Covered That Is Needed for The Study.

Statistical Tools: Chi-Square Analysis Was Carried Out to Examine the Cause of Stress Among Employee Using Spss21.

Analysis of Data: The Data Is Collected Through Survey and Books, Reports, Newspapers and Internet Etc., The Survey Conducted Among the Employees of Private Banks. The Data Collected Is Tabulated and Analyzed in Such A Way to Make Interpretations.

\section{DATA ANALYSIS AND INTERPRETATION}

The above objective is designed to study the causes of stress among employees in the selected banks so that the possible association between stress causing reasons among the employees of the selected employees is verified. Chisquare analysis is administered for the purpose verifying the stated hypothesis of no significant association between the causes of stress among employees in the selected banks. 
The stress causing reasons like

- Feel stressed when job tasks are not clear.

- Feel stressed when work overburdened

- Feel Late sitting causes fatigue

- Pressure of meeting unrealistic deadlines leads to stress

- Inappropriate reward system in organization is a reason of stress.

Are considered for the study.

- FEEL STRESSED WHEN JOB TASKS ARE NOT CLEAR

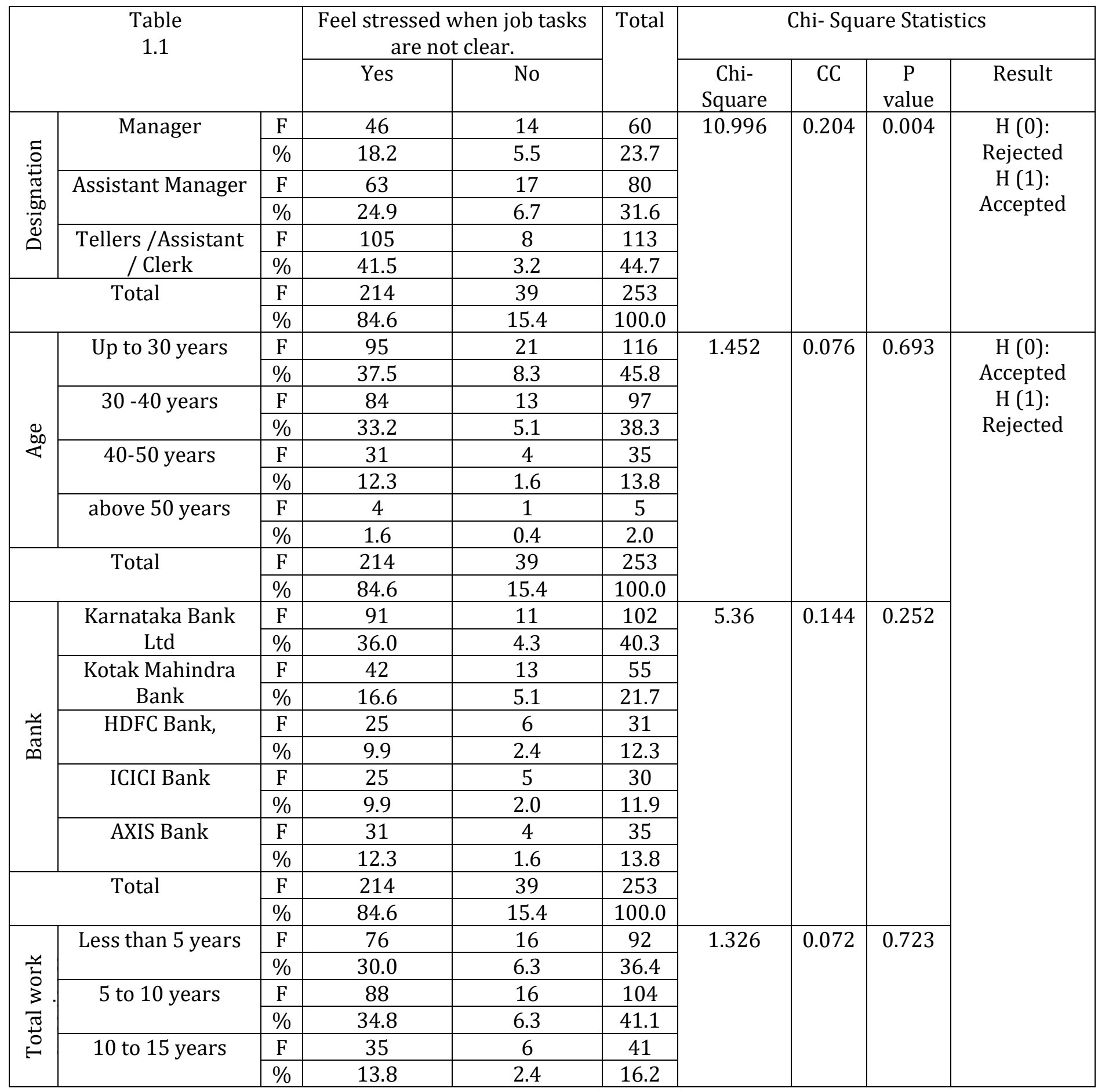


Cause of Stress Among Private Bank Employees: An Analysis

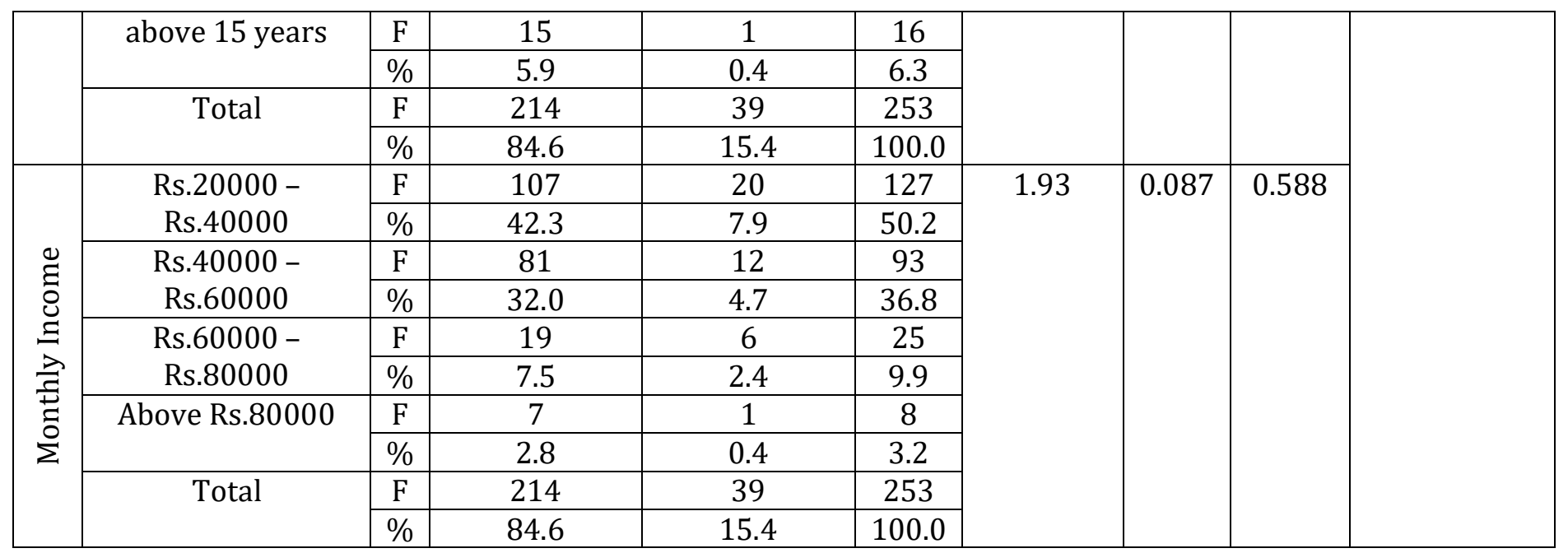

Source: authors' calculation

In aggregate $84.6 \%$ of the employees feel stressed when the job tasks are not clear.

The statistical hypothesis is found to be significantly associated with respect to the different designations of the employees and found that it is comparatively more prevalent among the clerical staff, which is found stressed when the job tasks are not clear. (H (0): Rejected, H (1): Accepted). Therefore, there is a significant association between the causes of stress among the employees in the selected banks with reference to their role designations.

However, with reference to the rest of the demographic variables like Age, Bank, Total work experience \& Monthly Income the statistical hypothesis is found to be non-significantly associated (H (0): Accepted, $H$ (1): Rejected). Therefore, there is no significant association between the causes of stress due to lack of clear guidelines of the tasks to be performed among the employees in the selected banks.

- FEEL STRESSED WHEN WORK OVERBURDENED

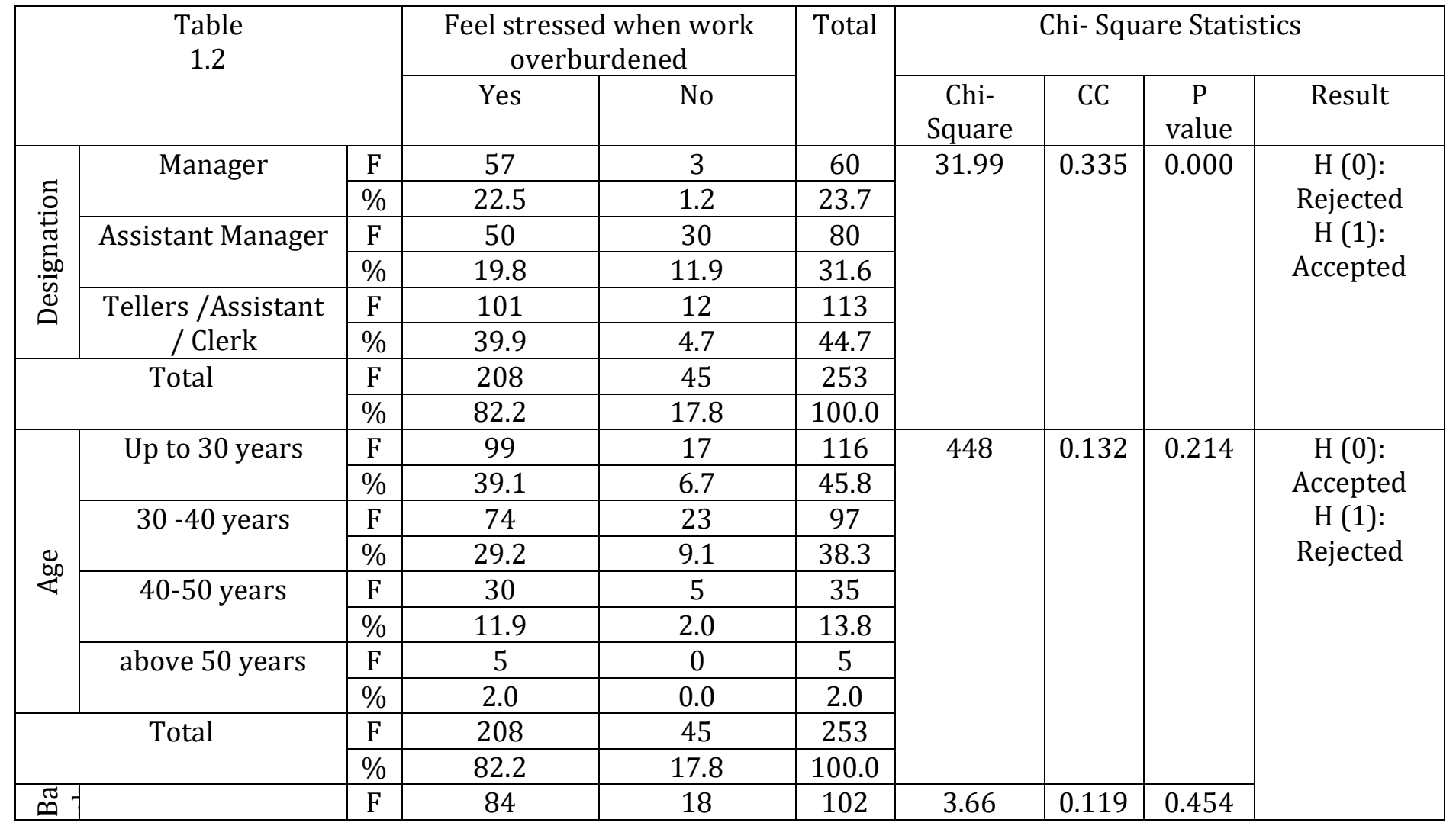




\begin{tabular}{|c|c|c|c|c|c|c|c|c|c|}
\hline & $\begin{array}{c}\text { Karnataka Bank } \\
\text { Ltd }\end{array}$ & $\%$ & 33.2 & 7.1 & 40.3 & & & & \\
\hline & Kotak Mahindra & $\mathrm{F}$ & 44 & 11 & 55 & & & & \\
\hline & Bank & $\%$ & 17.4 & 4.3 & 21.7 & & & & \\
\hline & HDFC Bank, & $\mathrm{F}$ & 29 & 2 & 31 & & & & \\
\hline & & $\%$ & 11.5 & 0.8 & 12.3 & & & & \\
\hline & ICICI Bank & $\mathrm{F}$ & 23 & 7 & 30 & & & & \\
\hline & & $\%$ & 9.1 & 2.8 & 11.9 & & & & \\
\hline & AXIS Bank & $\mathrm{F}$ & 28 & 7 & 35 & & & & \\
\hline & & $\%$ & 11.1 & 2.8 & 13.8 & & & & \\
\hline & Total & $\mathrm{F}$ & 208 & 45 & 253 & & & & \\
\hline & & $\%$ & 82.2 & 17.8 & 100.0 & & & & \\
\hline & Less than 5 years & $\mathrm{F}$ & 78 & 14 & 92 & 4.14 & 0.127 & 0.247 & \\
\hline$\underset{己}{\mathscr{E}}$ & & $\%$ & 30.8 & 5.5 & 36.4 & & & & \\
\hline 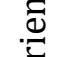 & 5 to 10 years & $\mathrm{F}$ & 80 & 24 & 104 & & & & \\
\hline$\stackrel{\overline{0}}{2}$ & & $\%$ & 31.6 & 9.5 & 41.1 & & & & \\
\hline$\sqrt[x]{d}$ & 10 to 15 years & $\mathrm{F}$ & 35 & 6 & 41 & & & & \\
\hline 刓 & & $\%$ & 13.8 & 2.4 & 16.2 & & & & \\
\hline 3 & above 15 years & $\mathrm{F}$ & 15 & 1 & 16 & & & & \\
\hline$\pi$ & & $\%$ & 5.9 & 0.4 & 6.3 & & & & \\
\hline$\stackrel{0}{6}$ & Total & $\mathrm{F}$ & 208 & 45 & 253 & & & & \\
\hline & & $\%$ & 82.2 & 17.8 & 100.0 & & & & \\
\hline & Rs.20000 - & $\mathrm{F}$ & 102 & 25 & 127 & 0.69 & 0.052 & 0.874 & \\
\hline & Rs.40000 & $\%$ & 40.3 & 9.9 & 50.2 & & & & \\
\hline$\stackrel{\varrho}{\Xi}$ & Rs.40000 - & $\mathrm{F}$ & 78 & 15 & 93 & & & & \\
\hline ర్ & Rs.60000 & $\%$ & 30.8 & 5.9 & 36.8 & & & & \\
\hline$\Xi$ & Rs.60000 - & $\mathrm{F}$ & 21 & 4 & 25 & & & & \\
\hline$\vec{\lambda}$ & Rs.80000 & $\%$ & 8.3 & 1.6 & 9.9 & & & & \\
\hline$\stackrel{\vec{\Xi}}{0}$ & Above Rs.80000 & $\mathrm{F}$ & 7 & 1 & 8 & & & & \\
\hline$\Sigma$ & & $\%$ & 2.8 & 0.4 & 3.2 & & & & \\
\hline & Total & $\mathrm{F}$ & 208 & 45 & 253 & & & & \\
\hline & & $\%$ & 82.2 & 17.8 & 100.0 & & & & \\
\hline
\end{tabular}

Source: authors' calculation

In aggregate $82.2 \%$ of the employees feel stressed when the work overburdened.

The statistical hypothesis is found to be significantly associated with respect to the different designations of the employees and found that it is comparatively more prevalent among the clerical staff, which is found stressed when thework overburdened. (H (0): Rejected, H (1): Accepted). Therefore, there is a significant association between the causes of stress among the employees in the selected banks with reference to their role designations.

However, with reference to the rest of the demographic variables like Age, Bank, Total work experience \& Monthly Income the statistical hypothesis is found to be non-significantly associated (H (0): Accepted, $\mathrm{H}$ (1): Rejected). Therefore, there is no significant association between the causes of stress due to overburdened work among employees in the selected banks.

\section{- FEEL LATE SITTING CAUSES FATIGUE}

\begin{tabular}{|c|c|c|c|c|c|c|c|c|c|}
\hline \multicolumn{3}{|c|}{$\begin{array}{c}\text { Table } \\
1.3\end{array}$} & \multicolumn{2}{|c|}{$\begin{array}{c}\text { Feel Late sitting causes } \\
\text { fatigue. }\end{array}$} & \multirow[t]{2}{*}{ Total } & \multicolumn{4}{|c|}{ Chi- Square Statistics } \\
\hline & & & Yes & No & & $\begin{array}{l}\text { Chi- } \\
\text { Square }\end{array}$ & CC & $\begin{array}{c}\mathrm{P} \\
\text { value }\end{array}$ & Result \\
\hline$\stackrel{0}{\circ}$ & Manager & $\mathrm{F}$ & 41 & 19 & 60 & 21.44 & 0.280 & 0.000 & \\
\hline
\end{tabular}


Cause of Stress Among Private Bank Employees: An Analysis

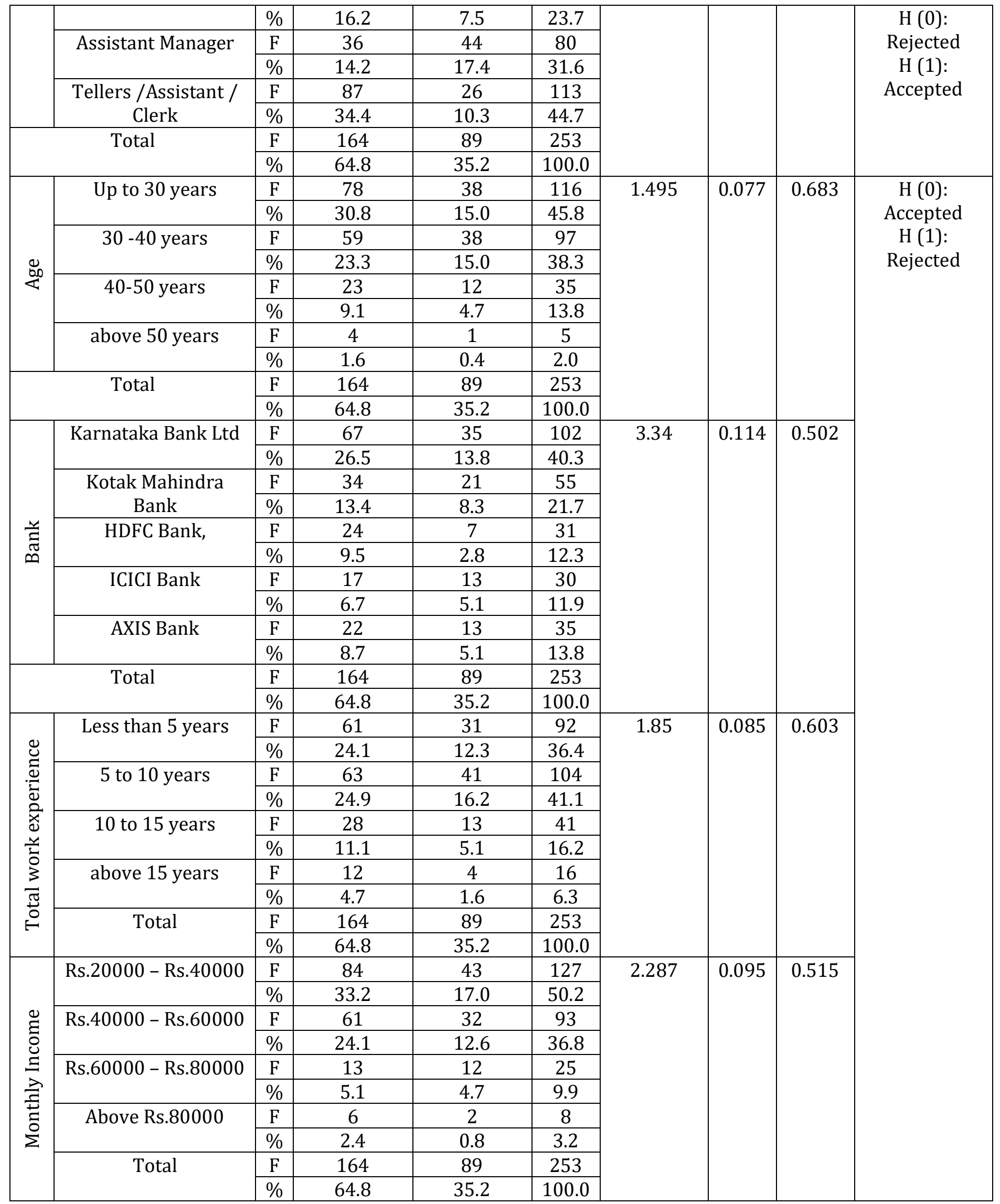

Source: authors' calculation 


\section{In aggregate $\mathbf{6 4 . 8 \%}$ of the employees Feel Late sitting causes fatigue thus indices stress}

The statistical hypothesis is found to be significantly associated with respect to the different designations of the employees and found that it is comparatively more prevalent among the clerical staff, which is found stressed while sitting late at the service counters. (H (0): Rejected, H (1): Accepted). Therefore, there is a significant association between the causes of stress among the employees in the selected banks with reference to their role designations.

However, with reference to the rest of the demographic variables like Age, Bank, Total work experience \& Monthly Income the statistical hypothesis is found to be non-significantly associated (H (0): Accepted, $H$ (1): Rejected). Therefore, there is no significant association between the causes of stress due to sitting late at the service counters among employees in the selected banks.

- PRESSURE OF MEETING UNREALISTIC DEADLINES LEADS TO STRESS

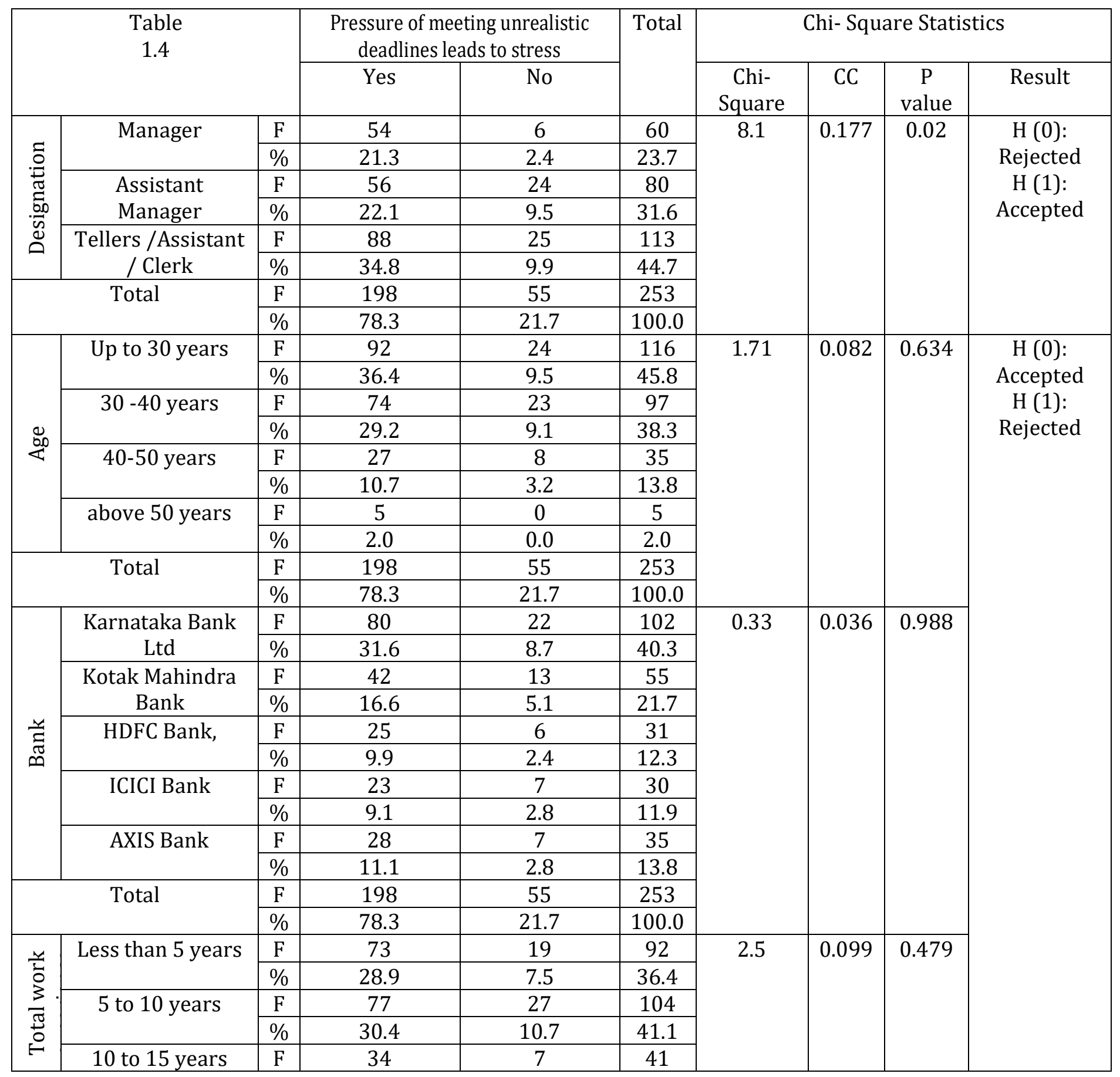


Cause of Stress Among Private Bank Employees: An Analysis

\begin{tabular}{|c|c|c|c|c|c|c|c|c|c|}
\hline & & $\%$ & 13.4 & 2.8 & 16.2 & & & & \\
\hline & above 15 years & $\mathrm{F}$ & 14 & 2 & 16 & & & & \\
\hline & & $\%$ & 5.5 & 0.8 & 6.3 & & & & \\
\hline & Total & $\mathrm{F}$ & 198 & 55 & 253 & & & & \\
\hline & & $\%$ & 78.3 & 21.7 & 100.0 & & & & \\
\hline & Rs.20000 - & $\mathrm{F}$ & 94 & 33 & 127 & 3.45 & 0.116 & 0.327 & \\
\hline & Rs.40000 & $\%$ & 37.2 & 13.0 & 50.2 & & & & \\
\hline$\stackrel{\varrho}{\Xi}$ & Rs.40000 - & $\mathrm{F}$ & 75 & 18 & 93 & & & & \\
\hline 8 & Rs.60000 & $\%$ & 29.6 & 7.1 & 36.8 & & & & \\
\hline$\Xi$ & Rs.60000 - & $\mathrm{F}$ & 22 & 3 & 25 & & & & \\
\hline $\overrightarrow{2}$ & Rs.80000 & $\%$ & 8.7 & 1.2 & 9.9 & & & & \\
\hline$\ddot{\Xi}$ & Above Rs.80000 & $\mathrm{F}$ & 7 & 1 & 8 & & & & \\
\hline$\Sigma$ & & $\%$ & 2.8 & 0.4 & 3.2 & & & & \\
\hline & Total & $\mathrm{F}$ & 198 & 55 & 253 & & & & \\
\hline & & $\%$ & 78.3 & 21.7 & 100.0 & & & & \\
\hline
\end{tabular}

Source: authors' calculation

In aggregate $78.3 \%$ of the employees feel stressed due to pressure of meeting un realistic deadlines.

The statistical hypothesis is found to be significantly associated with respect to the different designations of the employees and found that it is comparatively more widespread among the clerical staff, which is found stressed due to Pressure of meeting unrealistic deadlines. (H (0): Rejected, H (1): Accepted). Therefore, there is a significant association between the causes of stress among the employees in the selected banks with reference to their role designations.

However, with reference to the rest of the demographic variables like Age, Bank, Total work experience \& Monthly Income the statistical hypothesis is found to be non-significantly associated (H (0): Accepted, $H$ (1): Rejected). Therefore, there is no significant association between the causes of stress due to the pressures of meeting unrealistic deadlines.

- INAPPROPRIATE REWARD SYSTEM IN ORGANIZATION IS A REASON OF STRESS

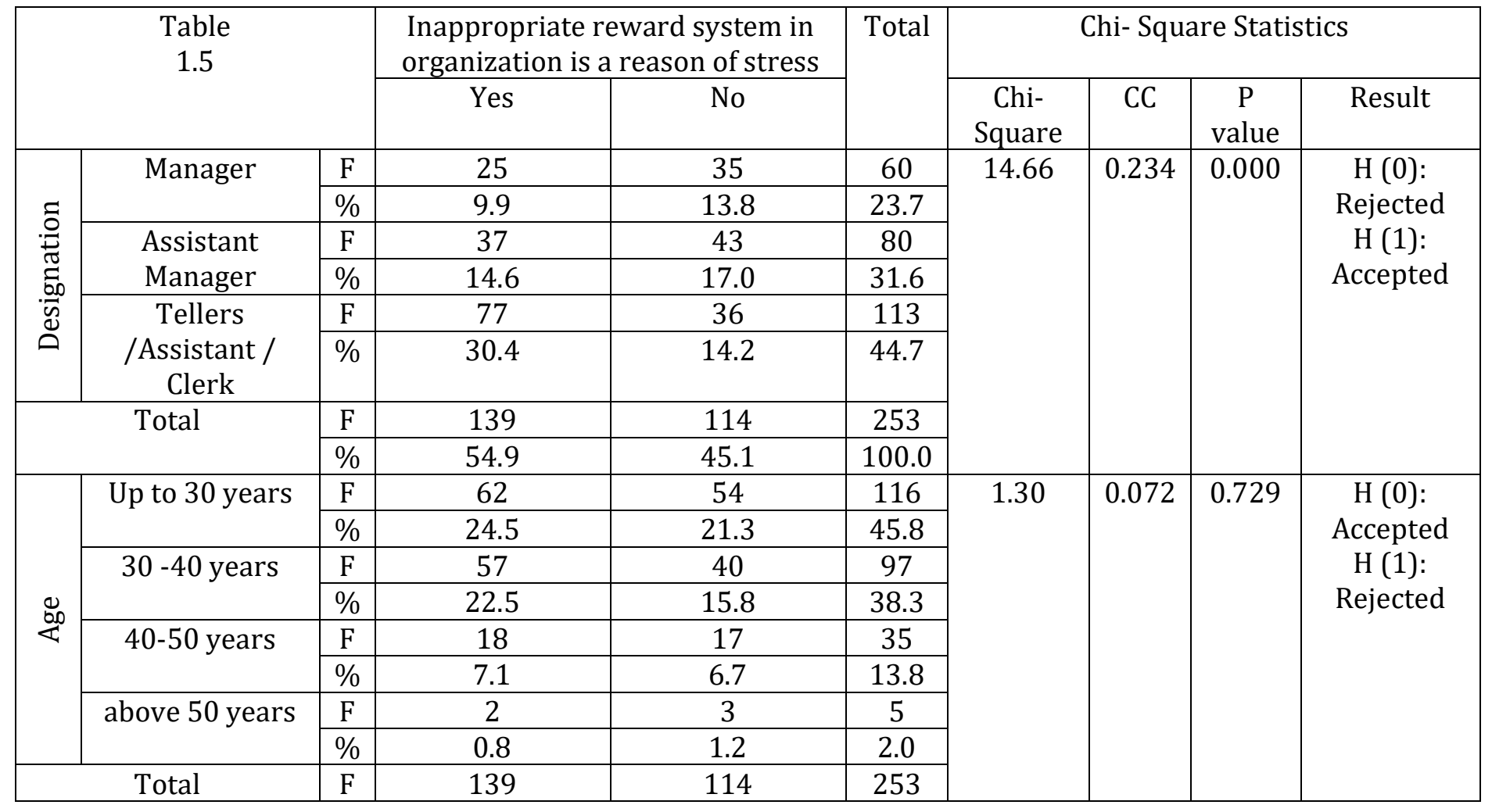


Manjunatha M K., and Dr. T. P. Renukamurthy

\begin{tabular}{|c|c|c|c|c|c|c|c|c|c|}
\hline \multirow{11}{*}{ 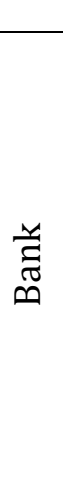 } & & $\%$ & 54.9 & 45.1 & 100.0 & & & & \\
\hline & \multirow{2}{*}{$\begin{array}{c}\text { Karnataka Bank } \\
\text { Ltd }\end{array}$} & $\mathrm{F}$ & 66 & 36 & 102 & \multirow[t]{12}{*}{10.79} & \multirow[t]{12}{*}{0.202} & \multirow[t]{12}{*}{0.029} & \multirow{12}{*}{$\begin{array}{c}H(0): \\
\text { Rejected } \\
H(1): \\
\text { Accepted }\end{array}$} \\
\hline & & $\%$ & 26.1 & 14.2 & 40.3 & & & & \\
\hline & \multirow{2}{*}{$\begin{array}{c}\text { Kotak Mahindra } \\
\text { Bank }\end{array}$} & $\mathrm{F}$ & 30 & 25 & 55 & & & & \\
\hline & & $\%$ & 11.9 & 9.9 & 21.7 & & & & \\
\hline & \multirow[t]{2}{*}{ HDFC Bank, } & $\mathrm{F}$ & 17 & 14 & 31 & & & & \\
\hline & & $\%$ & 6.7 & 5.5 & 12.3 & & & & \\
\hline & \multirow[t]{2}{*}{ ICICI Bank } & $\mathrm{F}$ & 10 & 20 & 30 & & & & \\
\hline & & $\%$ & 4.0 & 7.9 & 11.9 & & & & \\
\hline & \multirow[t]{2}{*}{ AXIS Bank } & $\mathrm{F}$ & 16 & 19 & 35 & & & & \\
\hline & & $\%$ & 6.3 & 7.5 & 13.8 & & & & \\
\hline \multirow{2}{*}{\multicolumn{2}{|c|}{ Total }} & $\mathrm{F}$ & 139 & 114 & 253 & & & & \\
\hline & & $\%$ & 54.9 & 45.1 & 100.0 & & & & \\
\hline \multirow{10}{*}{ 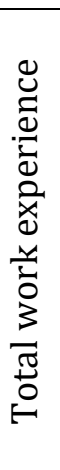 } & \multirow{2}{*}{$\begin{array}{l}\text { Less than } 5 \\
\text { years }\end{array}$} & $\mathrm{F}$ & 49 & 43 & 92 & \multirow[t]{10}{*}{0.87} & \multirow[t]{10}{*}{0.058} & \multirow[t]{10}{*}{0.833} & $H(0):$ \\
\hline & & $\%$ & 19.4 & 17.0 & 36.4 & & & & Accepted \\
\hline & \multirow[t]{2}{*}{5 to 10 years } & $\mathrm{F}$ & 57 & 47 & 104 & & & & $H(1):$ \\
\hline & & $\%$ & 22.5 & 18.6 & 41.1 & & & & Rejected \\
\hline & \multirow[t]{2}{*}{10 to 15 years } & $\mathrm{F}$ & 25 & 16 & 41 & & & & \\
\hline & & $\%$ & 9.9 & 6.3 & 16.2 & & & & \\
\hline & \multirow[t]{2}{*}{ above 15 years } & $\mathrm{F}$ & 8 & 8 & 16 & & & & \\
\hline & & $\%$ & 3.2 & 3.2 & 6.3 & & & & \\
\hline & \multirow[t]{2}{*}{ Total } & $\mathrm{F}$ & 139 & 114 & 253 & & & & \\
\hline & & $\%$ & 54.9 & 45.1 & 100.0 & & & & \\
\hline \multirow{10}{*}{ 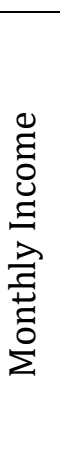 } & \multirow{2}{*}{$\begin{array}{l}\text { Rs.20000 - } \\
\text { Rs.40000 }\end{array}$} & $\mathrm{F}$ & 73 & 54 & 127 & \multirow[t]{10}{*}{1.19} & \multirow[t]{10}{*}{0.068} & \multirow[t]{10}{*}{0.755} & \\
\hline & & $\%$ & 28.9 & 21.3 & 50.2 & & & & \\
\hline & \multirow{2}{*}{$\begin{array}{c}\text { Rs.40000 - } \\
\text { Rs.60000 }\end{array}$} & $\mathrm{F}$ & 49 & 44 & 93 & & & & \\
\hline & & $\%$ & 19.4 & 17.4 & 36.8 & & & & \\
\hline & \multirow{2}{*}{$\begin{array}{c}\text { Rs. } 60000- \\
\text { Rs. } 80000\end{array}$} & $\mathrm{~F}$ & 12 & 13 & 25 & & & & \\
\hline & & $\%$ & 4.7 & 5.1 & 9.9 & & & & \\
\hline & \multirow[t]{2}{*}{ Above Rs.80000 } & $\mathrm{F}$ & 5 & 3 & 8 & & & & \\
\hline & & $\%$ & 2.0 & 1.2 & 3.2 & & & & \\
\hline & Total & $\mathrm{F}$ & 139 & 114 & 253 & & & & \\
\hline & & $\%$ & 54.9 & 45.1 & 100.0 & & & & \\
\hline
\end{tabular}

Source: authors' calculation

In aggregate $54.9 \%$ of the employees feel stressed due to inappropriate reward system

The statistical hypothesis is found to be significantly associated with respect to the different designations of the employees and found that it is comparatively more widespread among the clerical staff, which is found stressed due to Pressure of meeting unrealistic deadlines. (H (0): Rejected, H (1): Accepted). Therefore, there is a significant association between the causes of stress among the employees in the selected banks with reference to their role designations.

However, with reference to the rest of the demographic variables like Age, Bank, Total work experience \& Monthly Income the statistical hypothesis is found to be non-significantly associated (H (0): Accepted, $H$ (1): Rejected). Therefore, there is no significant association between the causes of stress due to the pressures of meeting unrealistic deadlines.

\section{CONCLUSION}

Our Study has led us to conclude that employees in private sectors bank employees face high levels of stress, of which they are subject to Designations the most. Further there is no significant association between the causes of stress among employees in the private bank. These results support the findings of a number of earlier studies e.g., Shanabhogara Raghavendra et al (2013) ${ }^{21}$, although we have noted that private sector banks facing slightly more 
Cause of Stress Among Private Bank Employees: An Analysis

stress. Our analysis of the impact of various demographic factors on stress levels reveals that employee's designations (Such as Manager, Assistant Manager, Tellers/Assistant/Clerk) have a significant impact on employee's stress levels.

\section{SOURCES OF FUNDING}

This research received no specific grant from any funding agency in the public, commercial, or not-for-profit sectors.

\section{CONFLICT OF INTEREST}

The author have declared that no competing interests exist.

\section{ACKNOWLEDGMENT}

None.

\section{REFERENCES}

[1] Madhu, K., Ananda, T. V. and Rao, A. N. (1990) Role Stress: Differential Influences of Some Antecedent Factors. Psychology Studies, 35(1), 28-35.

[2] Spreitzer, G.M., Kizilos, M.A. \& Nason, S.W. (1997) A dimensional analysis of the relationship between psychological empowerment and effectiveness, satisfaction, and strain. Journal of Management, 23(5), 679704.

[3] Barkat, S.A. and Asma, P. (1999) Gender and Age as Determinants of Organizational Role Stress. J.Com. Gui. Res., 16(2), 141-145.

[4] Pattanayak, B. (2000) "Role Stress in Indian Industries: Work life Dynamics", International Journal of Psychology, Vol, 35; and "Role Stress in Work Life Management in Public Sector", Social Science International, Vol.16 Scientific Papers.

[5] Jex, Bliese, Buzzell \& Primeau (2001) The impact of self-efficacy on stressor-strain relations: Coping style as an explanatory mechanism, Journal of Applied Psychology,86(3),401-409.

[6] Jac J L van der Klink, Roland W B Blonk, Aart H Schene, Frank J H van Dijk (2001) The benefits of interventions for work-related stress, American Journal of Public Health; Feb 2001; 91, 2.

[7] Suneel Khanna (2001) Mind Gym - Stress Management, Body Language. Team Building \& Leadership Skills"; The Business Magazine, Maclean's published bi-monthly 15th edition.

[8] Bhattacharya, Sunetra, Basu and Jayanthi, (2007) “Distress, Wellness and Organizational Role Stress among IT Professionals- Role of Life Events, Coping Resources".

[9] Rao and Pradhan (2007) "Perceived Work Deadlines - The Influence of Personality among Software Personnel”; Journal of the Indian Academy of Applied Psychology, July 2007, Vol. 33, No.2, 183-188.

[10] Raghavan, Sakaguchi, and Mahaney, (2008) "An Empirical Investigation of Stress Factors in Information Technology Professionals" Pages: 38-62. Volume 4, Issue 2 edited by Mehdi Khosrow-Pour.

[11] Randhir Singh Ranta, (2009) Management of Stress and Coping Behaviour of Police Personnel through Indian Psychological Techniques"; Journal of the Indian Academy of Applied Psychology, January 2009, Vol. 35, No.1, 47-53, Himachal Pradesh University, Shimla.

[12] Shilpa Sankpal, Dr Pushpa Negi and Jeetendra Vashishtha(2010) Organizational Role Stress of employees: Public VS Private Banks, Jul 2010, Vol. 3, Issue 1, The Indian Journal of Management.

[13] Garg Pratibha (2010) Stress Management among Private Sector Banking Professionals, Vol. 3(9) Sep. (2010), Advances in Management.

[14] Singh et al (2010) "Impact of Occupational Role Stress in Stress Management Amongst Public International) Management and Research, 314 (2/1), 20-24.

[15] S. Katyal M. Jain and B. Dhanda (2011) A Comparative Study of Job Stress and Type of Personality of Employees Working in Nationalized and Non-nationalized Banks, Kamla-Raj 2011, J Psychology, 2(2): 115-118 (2011). 
[16] K. S. Sathyanaraynan \& Dr. K. Maran (2011); A Study on Stress Management in IT Industry, Journal of Management Research \& Development, Vol. 1, No. 1, pp 21 - 26.

[17] Laiba Dar,Anum Akmal, Muhammad Akram Naseem,Kashif Ud Din Khan (2011) Impact of Stress on Employees Job Performance in Business Sector of Pakistan, Global Journal of Management and Business Research Volume 11 Issue 6 Version 1.0, ISSN: 0975-5853.

[18] Mohamed Irfann Ismail (2011) Identifying Work-Related Stress among Employees in the Malaysian Financial Sector, World Journal of Management, Vol. 3. No. 2. September 2011 Pp.229-243.

[19] Darling, J. R., \& Heller, V. L. (2011) The Key for Effective Stress Management: Importance of Responsive Leadership in Organizational. Organization Development Journal, 9-26.

[20] Makhbul, Zafir Mohd et al. (2011) Ergonomics and Work Stress Issues in Banking Sector. Australian Journal of Basic and Applied Sciences, 5(9), 1301-1309.

[21] Shanabhogara Raghavendra and B.G Srinivas (2013) Role of Stress and Job Performance among Banks Employees: An Analysis, Asian Journal of Managerial Science ISSN: 2249 - 6300 Vol. 2 No. 2, 2013, pp. 30-35. 